Review

\title{
Pt nanowire electrocatalysts for proton exchange membrane fuel cells
}

\author{
Zeyu Yan a,b, Bing Li a,b,*, Daijun Yang a,b, Jianxin Ma ${ }^{a, b}$ \\ a School of Automotive Studies, Tongji University, Shanghai 201804, China \\ ${ }^{\mathrm{b}}$ Clean Energy Automotive Engineering Center, Tongji University, Shanghai 201804, China
}

\section{A R T I C L E I N F O}

\section{Article history:}

Received 18 March 2013

Accepted 20 May 2013

Published 20 August 2013

Keywords:

Proton exchange membrane fuel cell

Electrocatalyst

Platinum

Nanowire

\section{A B S T R A C T}

The proton exchange membrane fuel cell (PEMFC) directly converts chemical energy into electricity with a high energy conversion rate, environmental friendliness, and the ability to start working quickly. The key material that determines the performance, lifetime, and cost of the PEMFC is the electrocatalyst, but the Pt catalyst used is very expensive, which is the major factor limiting the commercial use of the PEMFC. The Pt nanowire catalyst has demonstrated good performance in improving the utilization ratio of Pt, electrochemical activity, $\mathrm{CO}$ tolerance, and durability. This article reviewed the preparation and characterization of the Pt nanowire catalyst and its electrochemical activity.

(C) 2013, Dalian Institute of Chemical Physics, Chinese Academy of Sciences. Published by Elsevier B.V. All rights reserved.

\section{Introduction}

The fuel cell is a device that directly converts the chemical energy stored in the fuel and oxidant into electricity. It has many advantages, such as being highly effective (40\%-60\%) and environmentally friendly [1]. The proton exchange membrane fuel cell (PEMFC) further has the advantages of starting quickly at room temperature, simple structure, and high energy density. It can be the most suitable power source for propulsion applications in electrical vehicles [2], and it has drawn much attention from governments, enterprises, and research institutions. However, cost, durability, and the fuel supply infrastructure remain key problems blocking the successful commercialization of the PEMFC [3]. At present, Pt is used as its electrocatalyst because it is the most active material for both the anode and cathode [4-6], but this has hindered the process of commercialization because of the price and scarcity of Pt.
In recent years, much research has focused on reducing the precious metal loading while enhancing Pt utilization. One approach involves improving the Pt dispersion of the catalyst by applying new supports such as carbon nanotubes and carbon nanofibers [7-9]. A second approach is to improve the composition of catalyst, e.g., alloy catalysts, low Pt content catalysts, and even non-Pt catalysts [10-14]. A third approach is to modify the structure of the catalyst by designing and forming the structure at the nano-scale, thus changing the physical and chemical properties of the metal catalyst to get superior performance [15], including the use of a core-shell structure [16-18], nanostructured thin films $[19,20]$ and porous nanowires [21]. In particular, the Pt nanowire catalyst, which possesses distinctive structure and surface properties, has become a research hotspot for its high electrocatalytic activity, stability [22] and CO tolerance. This paper presents the preparation method for Pt nanowire catalysts and their applications in PEMFC.

\footnotetext{
*Corresponding author. Tel/Fax: +86-21-69583891; E-mail: libing210@tongji.edu.cn This work was supported by the National Natural Science Foundation of China (21206128) and China Postdoctoral Science Foundation (2012M510115). 


\section{Brief introduction to Pt nanowire catalyst}

For nano-materials, at least one of the three dimensions of space is in the nanoscale $(1-100 \mathrm{~nm})$, and nano-materials with their transverse size limited to below $100 \mathrm{~nm}$ are defined as nanowires [23,24]. A noble metal nanowire combines the excellent size effect of the nanowire with precious metal characteristics, shows special physical and chemical properties different from those of the bulk material, and has broad application prospects in the biomedical, sensor, conductive material, and chemical catalyst fields [25]. Recently, the Pd nanowire [26-28] and Pt nanowire [29-32] were employed as a PEMFC catalyst. The Pt particles supported on carbon will migrate during the operation of a fuel cell due to carbon corrosion. In addition, Pt nanoparticles are prone to Ostwald ripening because of their high surface area. These would lead to reduced electrochemical specific surface area and activity of the catalyst $[33,34]$. However, the Pt nanowire has a one-dimensional structure, which is much more stable. In addition, the highly ordered structure of the Pt nanowire is better for the multiphase mass transfer rate in the electrochemical reactions and it can be used as a good electron collector [35]. Thus, the catalytic activity and durability of the Pt nanowire is improved. At present, the $\mathrm{H}_{2}$ employed in the PEMFC is obtained from reforming of hydrocarbon and it usually contains CO impurity. CO is also the common intermediate product in the direct methanol fuel cell (DMFC). CO will poison the catalyst and reduce catalytic performance [36]. Some recent studies have shown that the adsorption of oxygen on a Pt nanowire is quite weak, so CO on the catalyst surface can move, which promotes the oxidation of the CO. As compared with a Pt nanoparticle catalyst, the nanowire shows better CO tolerance $[37,38]$.

The nanowire synthesis methods, including laser ablation, chemical vapor deposition, thermal vapor deposition,and template method, are fairly mature [24,39,40]. The template method is the main method to prepare the Pt nanowire. Scanning tunneling microscopy (STM), transmission electron microscopy (TEM), scanning electron microscopy (SEM), X-ray diffraction (XRD), and X-ray photoelectron spectroscopy (XPS) are the main means used to characterize the $\mathrm{Pt}$ nanowire $[41,42]$.

\section{Preparation of Pt nanowire and application in PEMFC}

\subsection{Hard template method}

The template method makes a material with a certain size and shape through its confinement ability. It can be divided into hard template and soft template methods according to the structure and characteristics of the template. The hard templates adopted for synthesizing Pt nanowires currently are porous anodic aluminum oxide (AAO) [35,43-46], mesoporous molecular sieves (MCM-41, SBA-15) [47-49], and organic polymers [50]. AAO is the most popular template because of its thermochemical stability, insulation property, controllable size, orderly arrangement, and feasibility [24]. Guan et al. [45] prepared PtPd alloy nanowire arrays by electrodepositing a mixed

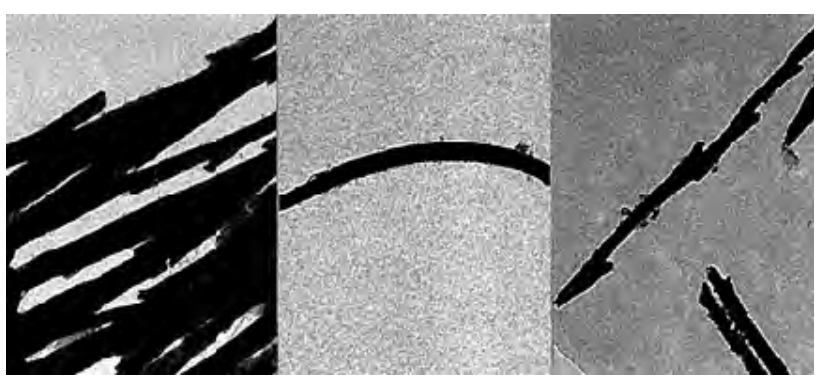

Fig. 1. TEM images of PdPt alloy nanowires [45].

solution of $\mathrm{PdCl}_{2}, \mathrm{H}_{2} \mathrm{PtCl}_{6}$, and $\mathrm{H}_{3} \mathrm{BO}_{3}$ with $\mathrm{AAO}$ as the template and investigated its morphology and size by TEM (Fig. 1) and the adsorption of $\mathrm{H}_{2}$.

Zhang et al. [35] synthesized Pt nanowire arrays (NWs) with diameters of 25 and $60 \mathrm{~nm}$ by electrodepositing a mixed solution of $\mathrm{H}_{2} \mathrm{PtCl}_{6}$ and $\mathrm{H}_{3} \mathrm{BO}_{3}$ with $\mathrm{AAO}$, and studied their activities for oxygen reduction reaction (ORR) as compared with a $20 \%$ $\mathrm{Pt} / \mathrm{C}$ catalyst commercially available from Johnson Matthey (JM). In Fig. 2, the results showed that the limiting current density of the commercial $\mathrm{Pt} / \mathrm{C}$ is $0.09 \mathrm{~mA} / \mathrm{cm}^{2}$, while those of 60 and $25 \mathrm{~nm}$ Pt NWs are 0.54 and $0.74 \mathrm{~mA} / \mathrm{cm}^{2}$, which are 6 and 8 times better, respectively, than the commercial Pt/C catalyst. The improved activities of the Pt NWs were ascribed to its highly ordered structure, which promoted the mass transfer rate and electron conductivity. Furthermore, the Pt NWs with a smaller diameter exhibit better performance because of higher specific electrochemical surface area (ECSA).

Sun et al. [47] fabricated PtRu NWs and nanorods with different alloy extents and aspect ratios by impregnating and reducing Pt and Ru precursors using SBA-15 and MCM-41 mesoporous molecular sieves, respectively, as the template. The results revealed that PtRu NWs synthesized using SBA-15 as the template had a higher alloy extent, larger aspect ratio, and better electrochemical catalytic activity for the methanol oxidation reaction (MOR) than the PtRu nanorods synthesized using the MCM-41 template. Park et al. [48] synthesized Pt NWs with diameters of $3 \mathrm{~nm}$ by reducing $\mathrm{Pt}\left(\mathrm{NH}_{3}\right)_{4}\left(\mathrm{NO}_{3}\right)_{2}$ with $\mathrm{H}_{2}$ using MCM-41 as the template and studied their activities for MOR. As compared with a commercial $\mathrm{Pt} / \mathrm{C}$, the area-normalized

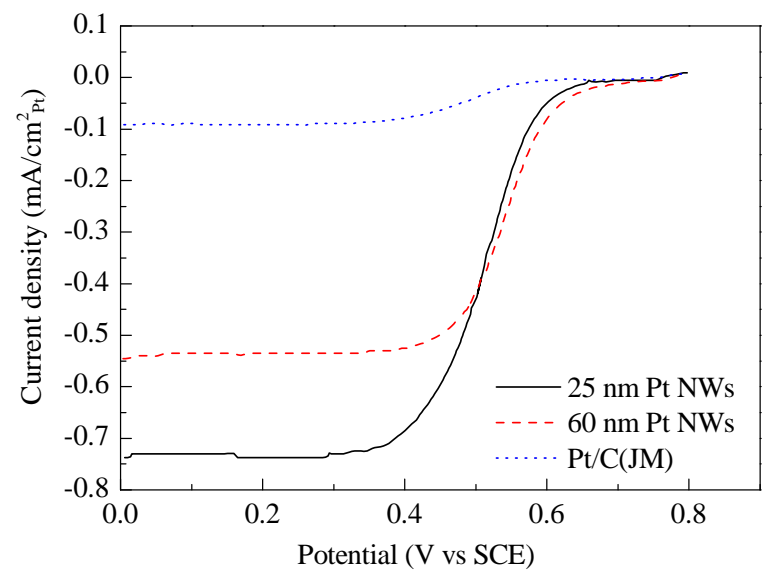

Fig. 2. Oxygen reduction reaction (ORR) polarization curves for the electrode in an $\mathrm{O}_{2}$-saturated $\mathrm{H}_{2} \mathrm{SO}_{4}$ solution (0.5 mol/L) [35]. 


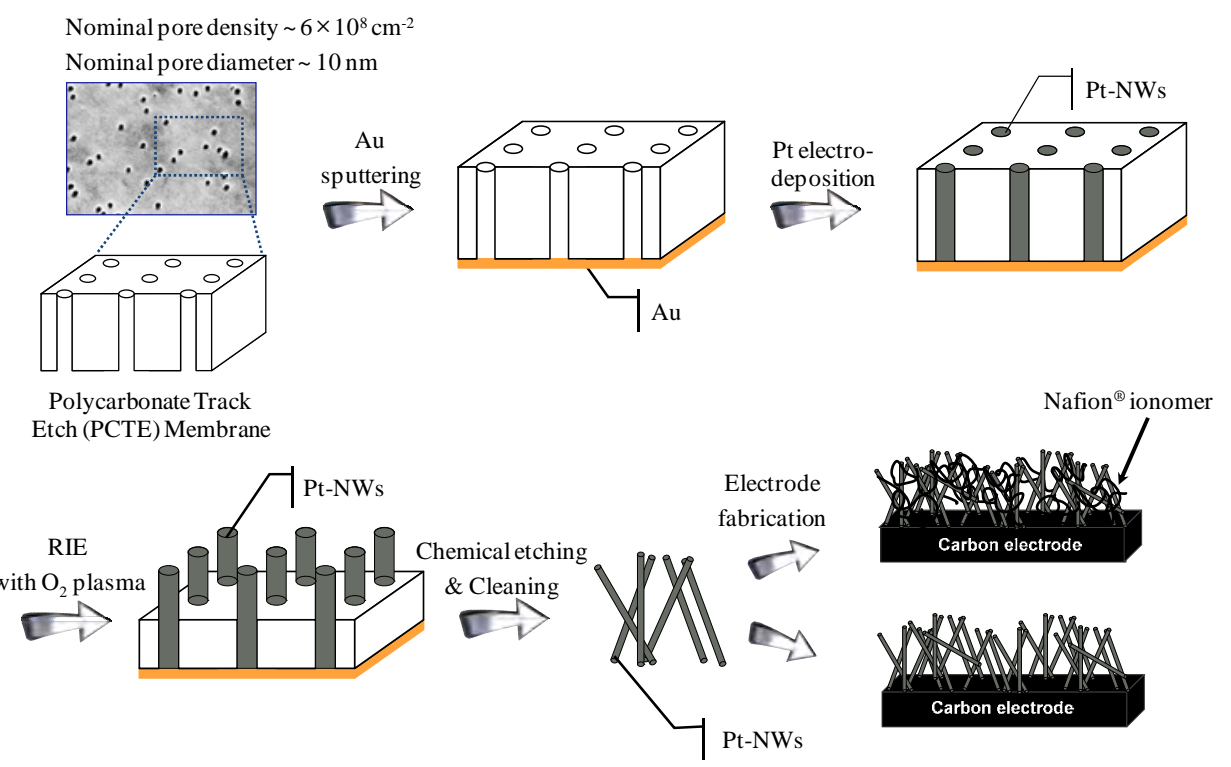

Fig. 3. Schematic illustration of the procedure for Pt nanowire preparation with the PCTE template membrane [50].

current densities of the $\mathrm{Pt} / \mathrm{C}$ and Pt NWs electrocatalysts were 443.30 and $113.20 \mu \mathrm{A} / \mathrm{cm}^{2}$, respectively, while the mass-normalized current densities of the Pt/C and Pt NWs electrocatalysts were 6.58 and $10.84 \mathrm{~A} / \mathrm{g}$ at $0.5 \mathrm{~V}$. Choi et al. [49] prepared PtRu alloy NWs by reducing $\left(\mathrm{NH}_{3}\right)_{4} \mathrm{Pt}\left(\mathrm{NO}_{3}\right)_{2}$ and $\left(\mathrm{NH}_{3}\right)_{6} \mathrm{RuCl}_{3}$ with SBA-15 as the template and revealed that the PtRu NW catalysts showed better performance for MOR both in half-cell and single cell testing as compared with a commercial PtRu black.

Choi et al. [50] synthesized Pt NWs that were $6 \mu \mathrm{m}$ long and $47 \mathrm{~nm}$ in diameter by electrodepositing a mixed solution of $\mathrm{H}_{2} \mathrm{PtCl}_{6}$ and $\mathrm{H}_{2} \mathrm{SO}_{4}$ into the pores of a track-etched polycarbonate (PCTE) membrane. The experimental procedure is illustrated in Fig. 3. The Pt NWs showed better oxidation activity for the CO species as well as better activity for MOR with a mass-normalized current density of $57.2 \mathrm{~mA} / \mathrm{mg}$, which is much higher than that of the commercial Pt/C (39.4 mA/mg) and Pt black (29.7 $\mathrm{mA} / \mathrm{mg})$ catalysts.

The AAO template, which has the characteristics of the same size of aperture, uniform distribution, and orderly arrangement, has been widely studied and adopted. The aperture diameter and film thickness of AAO can be controlled by the electrolytic conditions. The aperture of mesoporous molecular sieves is about $1.5-10 \mathrm{~nm}$, which is smaller than the AAO template (5-200 nm). Organic polymers are usually used in the template synthesis of nano-materials by the track etching treatment. The nano-materials synthesized with an organic polymer as template cannot form arrays orderly because its aperture distribution is uneven and irregular and because porous channels cross the membrane.

\subsection{Soft template method}

The soft template method refers to that the reaction is limited to the nanoscale porosity of the template agent by non-covalent forces. In combination with electrochemistry and precipitation techniques, it can effectively control the size and morphology of the synthetic materials through its limited space and regulation effect [51]. In current research, cetyltrimethylammonium bromide (CTAB) is the most commonly employed template for synthesizing Pt NWs.

In the research of Song and coworkers [52], $\mathrm{K}_{2} \mathrm{PtCl}_{4}$ aqueous solution was mixed with chloroform containing CTAB while stirring to build a two-phase water-chloroform system, which then formed a wormlike micellar network. The Pt complex confined within the inverse micellar network was then reduced by $\mathrm{NaBH}_{4}$ to produce Pt NWs that replicated the structure of the micellar network template. The proposed mechanism of formation is illustrated in Fig. 4. In addition, they also found that the morphology could be tuned somewhat by simply varying the stirring rate and $\mathrm{Pt}$ salt concentration. At a high stirring rate, large numbers of small chloroform droplets were produced that accelerated the diffusion of $\mathrm{NaBH}_{4}$ into the micelles, and this increased the rate of reduction of the $\mathrm{Pt}$ complex throughout the surfactant micellar network. Therefore, at a high stirring rate, rapid reduction captures a snapshot of the templating micellar network structure in the form of the $\mathrm{Pt}$ nanowire network. In contrast, at a slow stirring rate, due to the slower reaction rate, the growth rate was slow enough to allow the micellar template to adapt the growth to result in knob-like particles. The size of the Pt NWs was reduced at a low precursor concentration and even some separate particles were obtained, suggesting that there might be not enough $\mathrm{Pt}$ available to link up all the wires.

Yang and coworkers [53] synthesized Pt-based alloy (PtRu, PtPd, PtAu, and PtFe) nanowire networks (NWNs) on the basis of this approach and found that excessive and the strong reducing agent $\mathrm{NaBH}_{4}$ was needed when preparing PtFe NWs due to the big difference in the reduction potential of $\mathrm{Pt}^{4+}$ and $\mathrm{Fe}^{3+}$. Wang et al. [37] fabricated Pt NWNs electrocatalysts with an average diameter of $2.5 \mathrm{~nm}$ by this method and studied their activities for MOR and CO stripping as compared with a com- 


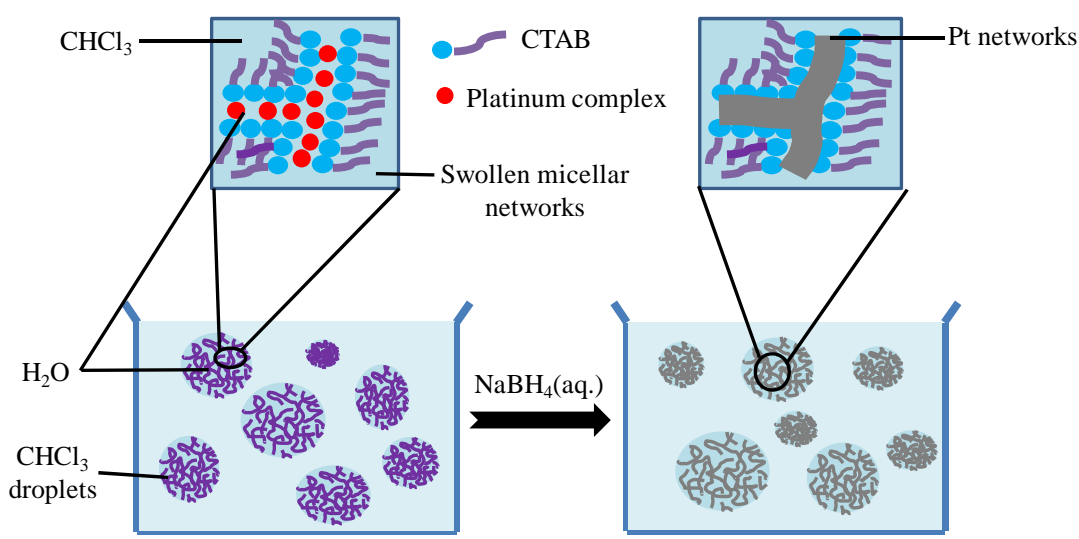

Fig. 4. Illustration of the forming of platinum nanowire networks using CTAB as a soft template [52].

mercial Pt/C catalyst. The CO stripping curves and cyclic voltammograms over the Pt NWNs/C and Pt nanoparticles (NPs)/C catalysts are illustrated in Fig. 5 and Fig. 6, respectively.

Figure 5 shows that the peak potential and onset potential for the adlayer CO oxidation on Pt NWNs/C was shifted negatively as compared to that for Pt NPs/C, indicating that the

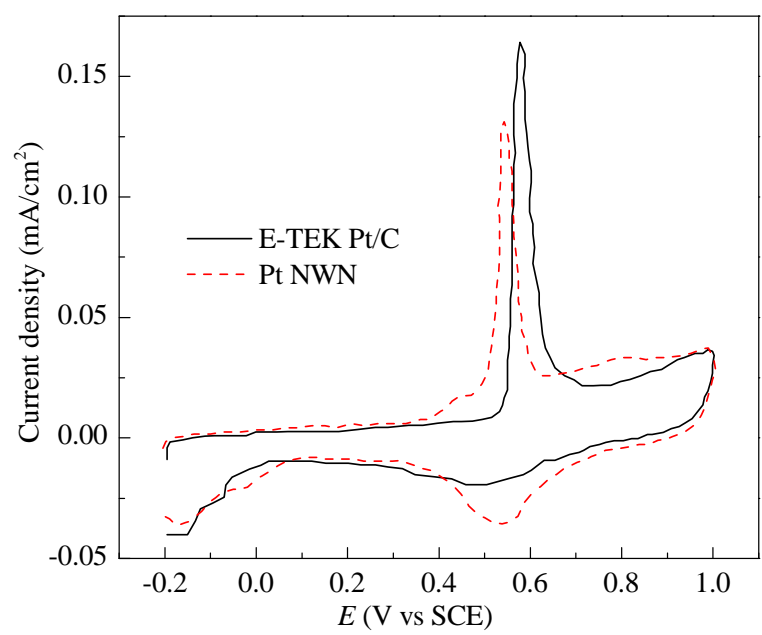

Fig. 5. CO stripping curves over Pt NWNs/C and Pt NPs/C catalysts [37].

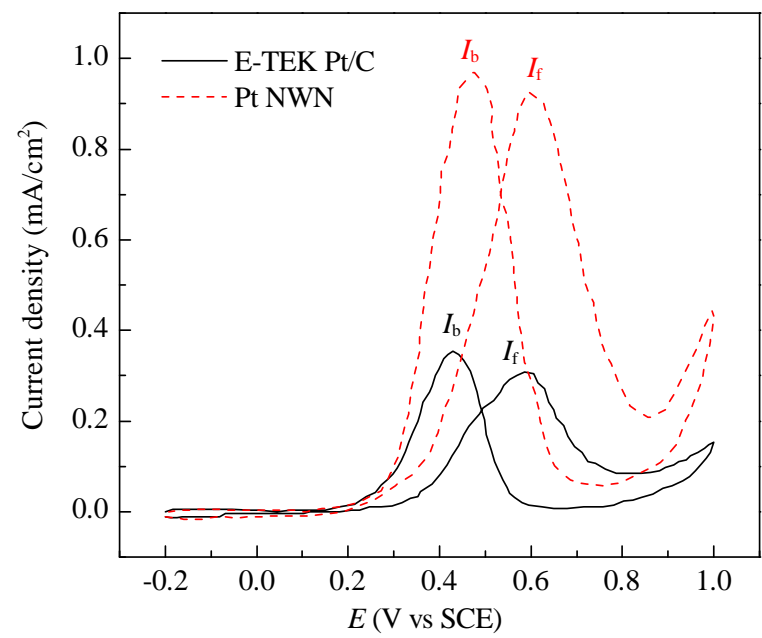

Fig. 6. Cyclic voltammograms of Pt NWNs/C and Pt NPs/C $(0.5 \mathrm{~mol} / \mathrm{L}$ $\mathrm{H}_{2} \mathrm{SO}_{4}+0.5 \mathrm{~mol} / \mathrm{L} \mathrm{MeOH}, 10 \mathrm{mV} / \mathrm{s}$ [ [37]. pre-adsorbed CO was easier to oxidize on Pt NWNs than on $\mathrm{Pt}$ NPs. The reaction scheme for electrochemical CO oxidation on Pt is

$$
\begin{gathered}
\mathrm{H}_{2} \mathrm{O}+\mathrm{Pt} \rightarrow \mathrm{Pt}-\mathrm{OH}_{\mathrm{ads}}+\mathrm{H}^{+}+\mathrm{e}^{-} \\
\mathrm{Pt}-\mathrm{CO}_{\text {ads }}+\mathrm{Pt}-\mathrm{OH}_{\mathrm{ads}} \rightarrow \mathrm{CO}_{2}+\mathrm{H}^{+}+\mathrm{e}^{-}+\mathrm{Pt}
\end{gathered}
$$

$\mathrm{CO}$ is oxidized when step (2) occurs between $\mathrm{CO}_{\text {ads }}$ and $\mathrm{OH}_{\mathrm{ads}}$ adsorbed on adjacent sites. Thus a high mobility of the adsorbates would facilitate the reaction. Pt NWNs have a weaker bonding with oxygen-containing species as compared with $\mathrm{Pt}$ NPs, which promotes the mobility of $\mathrm{CO}_{\text {ads }}$ and $\mathrm{OH}_{\text {ads. }}$ Therefore, the diffusion or intermixing of $\mathrm{CO}_{\text {ads }}$ and $\mathrm{OH}_{\text {ads }}$ would be easier on Pt NWNs than Pt NPs, resulting in the faster electrooxidation of $\mathrm{CO}_{\text {ads. }}$ In addition, with the formation of interconnected nanowires, more defect sites are generated in $\mathrm{Pt}$ NWNs, producing extra active reaction sites. In summary, Pt NWNs showed better $\mathrm{CO}$ tolerance because the $\mathrm{CO}$ absorbed on them can be oxidized more easily.

In Fig. 6, the peak current densities associated with methanol oxidation in the anodic scan are $0.96 \mathrm{~mA} / \mathrm{cm}^{2}$ for $\mathrm{Pt}$ NWNs/C and $0.29 \mathrm{~mA} / \mathrm{cm}^{2}$ for the reaction on Pt NPs/C, indicating that Pt NWNs/C catalysts showed a much higher specific activity for the MOR. On the other hand, the current peak ratio of If (the anodic peak current density)/Ib (the cathodic peak current density) indicated the CO tolerance of the Pt catalysts. The $I_{\mathrm{f}} / I_{\mathrm{b}}$ ratio was 0.96 for the Pt NWNs/C, which was higher than the 0.76 for the reaction on $\mathrm{Pt} N \mathrm{Ns} / \mathrm{C}$, indicating that $\mathrm{Pt}$ NWNs have enhanced CO tolerance as compared to Pt NPs.

Li et al. [38] prepared Pt-Ru alloy NWNs by the same method and found that the synthesis conditions, such as the amount of reducing agent and atomic ratio of $\mathrm{Pt}$ to $\mathrm{Ru}$, had a significant impact on the activity of the Pt-Ru NWNs electrocatalysts. The $\mathrm{Pt}-\mathrm{Ru} \mathrm{NWNs}$ possessed the highest MOR activity when the amount of reducing agent was $0.4 \mathrm{~g}$ and the atomic ratio of $\mathrm{Pt}: \mathrm{Ru}$ was $1: 1$. The current density obtained from $\mathrm{CV}$ at $0.7 \mathrm{~V}$ was $30.95 \mathrm{~mA} / \mathrm{cm}^{2}$ for the Pt-Ru NWNs, which is superior to that of $23.5 \mathrm{~mA} / \mathrm{cm}^{2}$ for Pt-Ru black, which was the best catalyst for MOR and CO tolerance in reported data.

\subsection{Other methods}

Besides the template methods, some researchers have developed a facile wet chemical procedure to synthesize Pt NWs 
by the reduction of $\mathrm{H}_{2} \mathrm{PtCl}_{6}$ with $\mathrm{HCOOH}$ at room temperature, without surfactant or template [54-58]. Pt is reduced according to the reaction:

$$
\mathrm{H}_{2} \mathrm{PtCl}_{6}+2 \mathrm{HCOOH} \rightarrow \mathrm{Pt}+6 \mathrm{Cl}-6 \mathrm{H}^{+}+2 \mathrm{CO}_{2} \uparrow
$$

The growth mechanisms of nanowires and branched nanowires of Pt are not fully understood yet, but it is believed that anisotropic growth, preferentially in the $<111>$ direction, is promoted by the very slow reduction rate at room temperature and the lowest energy principle. [54] Sun et al. [55] developed Pt NWs by directly growing these on multiwalled carbon nanotubes (MWCNTs) with the reduction of $\mathrm{H}_{2} \mathrm{PtCl}_{6}$ with $\mathrm{HCOOH}$ at room temperature for $3 \mathrm{~d}$. The schematic diagrams and corresponding TEM images are illustrated in Fig. 7.

Sun et al. [56] fabricated Pt NWs supported on Vulcan XC72 and found that the length and growth density of the Pt NWs can be easily controlled by adjusting the reduction time and weight ratio for Pt precursor to carbon, respectively. They also investigated the fuel cell performance of a selected Pt NWs/C catalyst and compared it with a state-of-the-art commercial membrane electrode assembly (MEA) in Fig. 8. The Pt NWs/C catalyst exhibited a better performance (about 10-12 $\mathrm{mV}$ higher at a given current) than the commercial $\mathrm{Pt} / \mathrm{C}$ catalyst. The main reason for the enhanced performance was ascribed to the better ORR kinetics of their synthesized cathode.

The relevant parameters for characterizing the performance of both MEAs with different catalysts are summarized in Table 1. The MEA with Pt NWs as catalyst showed better performance with a lower Pt loading. The Pt NWs catalyst possesses a smaller electrochemically active surface area as compared to the Pt NPs because of its size and interconnected structure. However, the Pt NWs catalyst exhibited 50\% higher mass activity than the commercial cathode, which may be due to the preferential exposure of certain crystal facets of Pt the NWs and that its highly ordered structure facilitated the reaction kinetics and improved $\mathrm{O}_{2}$ diffusion to Pt surface.

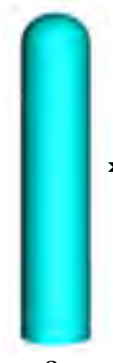

a

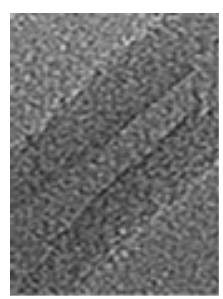

$\mathrm{a}^{\prime}$

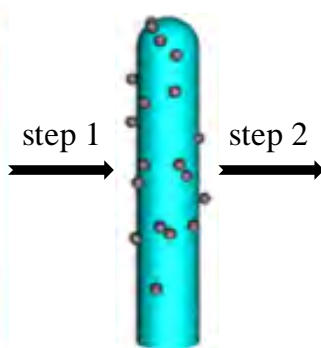

b

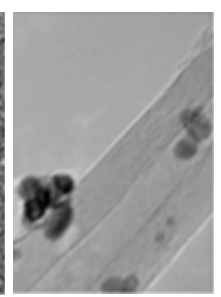

$b^{\prime}$

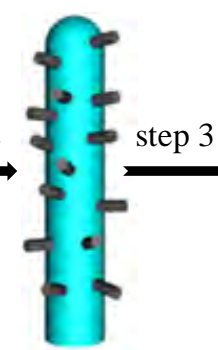

C

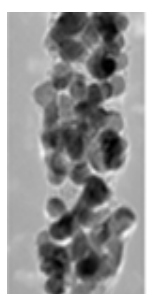

$\mathrm{C}^{\prime}$

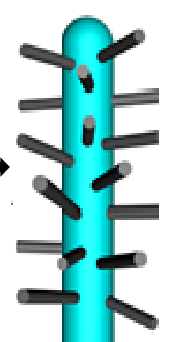

d

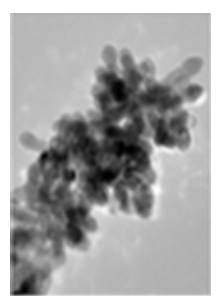

$d^{\prime}$
Fig. 7. Schematic of the formation and shape evolution of $\mathrm{Pt}$ NW-MWCNT heteronanostructures. (a-d) Schematic of the growth steps of the heteronanostructures; (a'-d') TEM photomicrographs corresponding to $(\mathrm{a}-\mathrm{d})$, respectively [55].

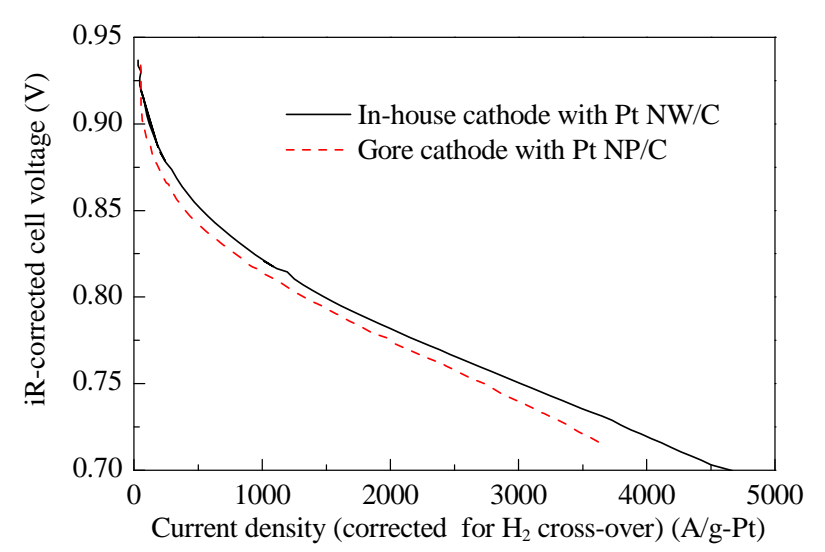

Fig. 8. Comparison of cathode polarization curves of a Gore MEA and an in-house MEA [56].

Sun et al. [54] prepared carbon-supported multi-armed starlike Pt NWs and investigated their durability through an accelerated durability test (ADT) for 4000 cycles, and compared it with a commercial Pt NPs/C. The results showed that the Pt NWs/C had better durability. In addition, the durability can be further improved by removing the carbon support and its corrosion effect, indicating the stable structure of the $\mathrm{Pt}$ NWs.

In Fig. 9, the commercial Pt/C showed a large loss in the hydrogen adsorption-desorption peak area in the cyclic voltammetry after 4000 cycles, which demonstrated quite severe loss of the initial Pt ECSA. The results showed that the commercial $\mathrm{Pt} / \mathrm{C}$ catalyst had lost $67.5 \%$ of the initial ECSA, while the $\mathrm{Pt}$ NWs/C and unsupported Pt NWs had lost $40 \%$ and 13\%, respectively, which indicated that the Pt NWs/C and unsupported Pt NWs possessed better durability.

The degradation in the performance of different catalysts was also observed. As shown in Fig. 10, the commercial Pt/C showed significant degradation with a large decrease of $88 \mathrm{mV}$ in the half-wave potential. However, Pt NWs/C and unsupported Pt NWs showed small negative shifts of 20 and $9 \mathrm{mV}$, respectively. The scheme of morphology changes that occurred in different electrocatalysts during the test are illustrated in Fig. 11. The major reason for the Pt ECSA loss of Pt/C during the test was due to $\mathrm{Pt}$ nanoparticles ripening, aggregation, and carbon support corrosion. In contrast, the Pt NWs catalyst maintained the same shape and showed only slight aggregation, which may be due to corrosion of the carbon support, because of its stable 1D structure and lower surface energy. The results showed that Pt NWs had better durability owning to its special structure.

Lee et al. [59] prepared Pt NWs by atomic layer deposition

Table 1

Mass and specific activities for ORR and electrochemical Pt area of the cathodes.

\begin{tabular}{lcccc}
\hline MEA & $\begin{array}{c}\text { Pt } \\
\text { loading } \\
(\mathrm{mg})\end{array}$ & $\begin{array}{c}\text { Pt electrochemical } \\
\text { specific area } \\
\left(\mathrm{cm}^{2} / \mathrm{mg}\right)\end{array}$ & $\begin{array}{c}\text { Current } \\
\text { density at 0.9 V } \\
\left(\mathrm{mA} / \mathrm{cm}^{2}\right)\end{array}$ & $\begin{array}{c}\text { ORR activity } \\
\text { at 0.9 V per } \\
\text { mass }(\mathrm{A} / \mathrm{g})\end{array}$ \\
\hline Pt NWs & 0.35 & 436 & 42.0 & 120 \\
Gore 5510 & 0.40 & 876 & 31.6 & 79 \\
\hline
\end{tabular}



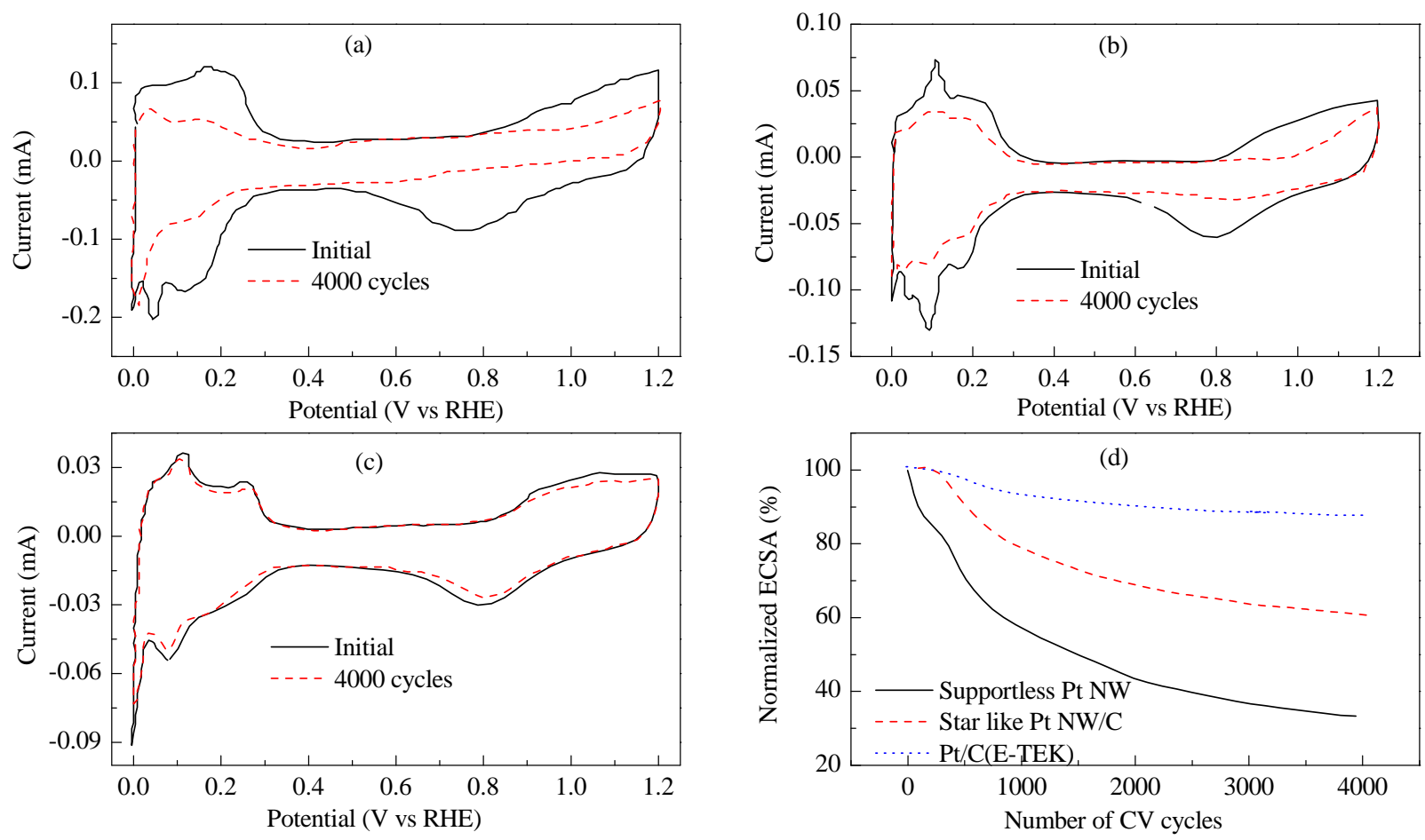

Fig. 9. CV curves for different catalysts before and after 4000 cycles. (a) E-TEK Pt/C; (b) Star-like Pt NWs/C; (c) Supportless Pt NWs; (d) Loss of electrochemical surface area (ECSA) [54].

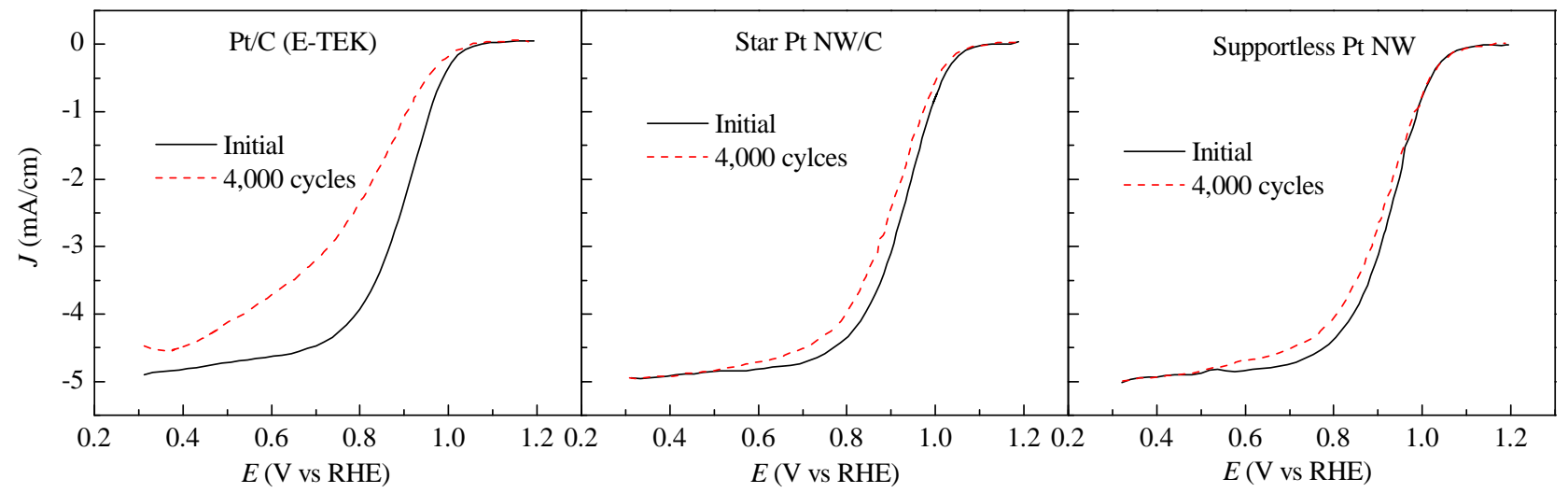

Fig. 10. ORR polarization curves before and after 4,000 cycles [54].

(ALD) on the step edges with defect sites of highly ordered pyrolytic graphite (HOPG) composed of stacked graphene layers, and demonstrated that the diameter of the Pt NWs can be controlled by changing the number of ALD cycles. Li et al. [60] fabricated a single Pt nanowire electrode by the HF etching process from a Pt disk nanoelectrode and an underpotential deposition (UPD) redox replacement technique. The results revealed that the shorter electrode is more active due to its high mass transfer rate, besides, the tip end position was more active than the sidewall position. In the research of Shen and coworkers [61], $\mathrm{Na}_{2} \mathrm{Pt}(\mathrm{OH})_{6}$ as the precursor was dropped onto $\mathrm{TiO}_{2}$ coated substrates, and then the samples were isothermally heated at $300{ }^{\circ} \mathrm{C}$ for $3 \mathrm{~h}$ in air by an infrared furnace. The Pt NWs, with an average diameter of $34 \mathrm{~nm}$ and the remarkable length of $6 \mu \mathrm{m}$ (a superb aspect ratio of up to 200), were prepared using the excellent photocatalytic feature of $\mathrm{TiO}_{2}$.
Overall, the Pt NWs prepared by the soft template method have small diameters of about $2.5 \mathrm{~nm}$. The hard template method can be used to prepare Pt NWs with a uniform and controlled morphology and as nanowire arrays. The direct reduction method using $\mathrm{HCOOH}$ can form single crystal structure nanowires. For the hard template method, there are four main drawbacks. First, the metal interconnectivity of the catalyst is bad due to the poor continuity of the hard template. Second, it can cause serious environment and safety issues because of the use of hydrofluoric acid to removal the hard template. Third, the whole structure of the hard template usually restricts the catalyst structure and size. Lastly, it is expensive and difficult to use on a large scale. Meanwhile, the soft template method can easily and flexibly control the structure and size of the Pt NWs catalyst, and it is also environmentally friendly, low cost, and easy to scale up. 

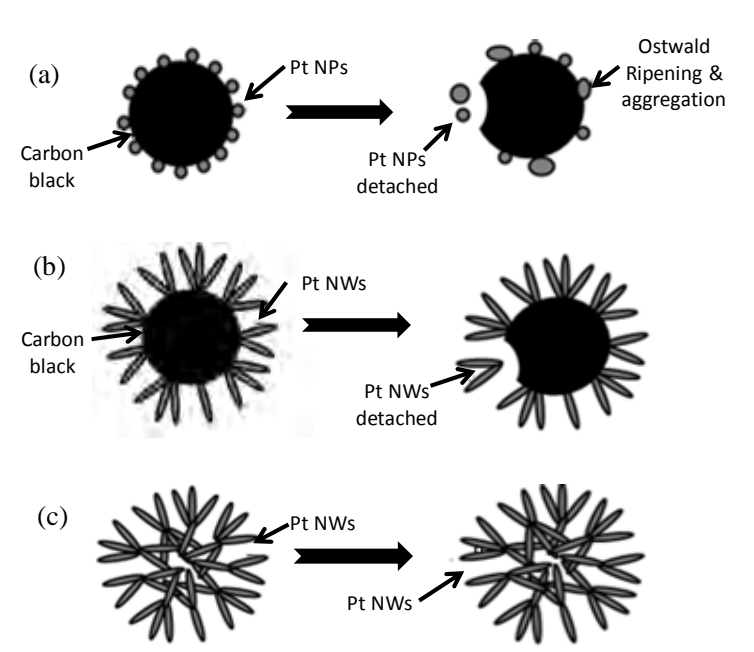

Fig. 11. Schematic of morphology changes to Pt during accelerated electrochemical cycling. (a) E-TEK Pt/C; (b) Pt NWs/C; (c) Pt NWs [54].

\section{Conclusions}

To reduce Pt loading and improve the utilization of Pt to develop a Pt electrocatalyst with high performance is of great significance for promoting the commercialization of the fuel cell. The ORR and MOR performance and CO tolerance of Pt NWs are superior to those of commercial Pt NP catalysts, which is due to that the former contains a special one-dimensional structure and has special surface properties. The preparation methods, including the hard template method (AAO, mesoporous molecular sieves as template), soft template method (CTAB as template), and self-assembly method $\left(\mathrm{H}_{2} \mathrm{PtCl}_{6}\right.$ is reduced by $\mathrm{HCOOH}$ at room temperature), are becoming mature. Therefore, the Pt NW catalyst is the most promising way to reduce the Pt content in the electrochemical catalyst. There are still several problems to be solved, namely: (1) to develop a preparation method that can easily control the Pt NW shape and structure and that is easy to scale up, (2) to understand the effects of the special structure of nanowires on its electro-catalytic kinetics, and (3) to explore the mechanism to improve catalyst electro-activity and develop the theoretical basis for the development of a high performance catalyst.

\section{References}

[1] Yi B L. Fuel Cells. Beijing: Chem Ind Press (衣宝廉. 燃料电池. 北 京: 化学工业出版社), 2003.2

[2] Li B, Li H, Ma J X, Wang H J. J Automotive Safety and Energy (李冰, 李辉, 马建新, 王海江. 汽车安全与节能学报), 2010, 1: 260

[3] Nie M, Zhang L Y, Li Q He B. Surf Technol (聂明, 张连营, 李庆, 何 璧. 表面技术), 2012, 41(3): 109

[4] Zhang J M, Wen M, Li Y, Guan W M. Precious Metals (张俊敏, 闻明, 李旸, 管伟明. 贵金属), 2010, 31(2): 67

[5] Fan B, Guo Y G, Wan L J. Prog Chem (樊博, 郭玉国, 万立骏. 化学 进展), 2010, 22: 852

[6] Xu H F, Lin Z Y, Qiu Y L, Tang Q. Chin J Catal (徐洪峰, 林志银, 邱艳 玲, 唐倩. 催化学报), 2003, 24: 143

[7] An X S, Fan Y J. Mater Rev (安䈗莎, 樊友军. 材料导报), 2010, 24(1): 64

[8] Wang X Z, Fu R, Zheng J S, Ma J X. Acta Phys-Chim Sin (王喜照, 符
蓉, 郑俊生, 马建新. 物理化学学报), 2011, 27: 1875

[9] Li W Z, Liang C H, Xin Q. Chin J Catal (李文震, 梁长海, 辛勤. 催化 学报), 2004, 25: 839

[10] Li B. [PhD Dissertation]. Shanghai: Tongji University (李冰. [博士 学位论文]. 上海: 同济大学), 2011

[11] Fu R, Zheng J S, Zhang Y K, Wang X Z, Ma J X. Chin J Power Sources (符蓉, 郑俊生, 张元鲲, 王喜照, 马建新. 电源技术), 2012, 36: 416

[12] Cui C H. [PhD Dissertation]. Hefei: University of Science and Technology of China (崔春华. [博士学位论文]. 合肥: 中国科学技 术大学), 2011

[13] Su H. [PhD Dissertation]. Beijing: Graduate University of Chinese Academy of Sciences (苏虹. [博士学位论文]. 北京: 中国科学院研 究生院), 2009

[14] Luo Y L, Liang Z X, Liao S J. Chin J Catal (罗远来, 梁振兴, 廖世军. 催化学报), 2010, 31: 141

[15] Zong J, Huang C D, Wang Y X. Battery (宗军, 黄成德, 王宇新. 电 池), 2011, 41(2): 104

[16] Zhang H Y, Cao C H, Zhao J, Lin R, Ma J X. Chin J Catal (张海艳, 曹春 晖, 赵健, 林瑞, 马建新. 催化学报), 2012, 33: 222

[17] Liu B, Liao S J, Liang Z X. Prog Chem (刘宾, 廖世军, 梁振兴. 化学 进展), 2011, 23: 852

[18] Cao C H, Lin R, Zhao T T, Huang Z, Ma J X. Acta Phys-Chim Sin (曹春 晖, 林瑞, 赵天天, 黄真, 马建新. 物理化学学报), 2013, 29: 95

[19] Gancs L, Kobayashi T, Debe M K, Atanasoski R, Wieckowski A. Chem Mater, 2008, 20: 2444

[20] Bonakdarpour A, Stevens K, Vernstrom G D, Atanasoski R, Schmoeckel A K, Debe M K, Dahn J R. Electrochim Acta, 2007, 53: 688

[21] Zhang X Y, Lu W, Da J Y, Wang H T, Zhao D Y, Webley P A. Chem Commun, 2009: 195

[22] Liang H W, Cao X, Zhou F, Cui C H, Zhang W J, Yu S H. Adv Mater, 2011, 23: 1467

[23] Guo Y G. [PhD Dissertation]. Qingdao: Qiangdao University (郭玉 国. [博士学位论文]. 青岛: 青岛大学), 2001

[24] Zhou Y H. Guangdong Chem Ind (周延辉. 广东化工), 2012, 39(3): 108

[25] Qiao Z Y, Liu F L, Xiao P, Qaio L, Yang Y N, Fang H L, Zhang Y H. Chemical Ind Eng Prog (乔正阳, 刘非拉, 肖鹏, 乔雷, 杨艳南, 房 红琳, 张云怀. 化工进展), 2012, 31: 2252

[26] Xu M L, Zhang Z F, Yang X W. Rare Metal Mater Eng (徐明丽, 张正 富, 杨显万. 稀有金属材料与工程), 2010, 39: 129

[27] Wang S Y, Wang X, Jiang S P. Nanotechnology, 2008, 19: 455602

[28] Wang J J, Chen Y G, Liu H, Li R Y, Sun X L. Electrochem Commun, 2010, 12: 219

[29] Shimizu W, Okada K, Fujita Y, Zhao S S, Murakami Y. J Power Sources, 2012, 205: 24

[30] Wang H H, Zhou Z Y, Yuan Q, Tian N, Sun S G. Chem Commun, 2011, 47: 3407

[31] Zhang Z T, Blom D A, Gai Z, Thanpson J R, Shen J, Dai S. J Am Chem Soc, 2003, 125: 7528

[32] Kim J M, Joh H I, Jo S M, Ahn D J, Ha H Y, Hong S A, Kim S K. Electrochim Acta, 2010, 55: 4827

[33] Hu L. [PhD Dissertation]. Suzhou: Suzhou University (胡否. [博士 学位论文]. 苏州: 苏州大学), 2012

[34] Chen W M, Xin Q, Sun G Q. Chin J Catal (陈维民, 辛勤, 孙公权. 催 化学报), 2008, 29: 497

[35] Zhang M, Li J J, Pan M, Xu D S. Acta Phys-Chim Sin (张敏, 李经建, 潘牧, 徐东升. 物理化学学报), 2011, 27: 1685

[36] Liu F F, Lu M. Telecom Power Technol (刘丰峰, 卢玫. 通信电源技 术), 2009, 26(2): 25

[37] Wang S Y, Jiang S P, Wang X, Guo J. Electrochim Acta, 2011, 56: 


\section{Graphical Abstract}

Chin. J. Catal., 2013, 34: 1471-1481 doi: 10.1016/S1872-2067(12)60629-9

\section{Pt nanowire electrocatalysts for proton exchange membrane fuel cells}

Zeyu Yan, Bing Li *, Daijun Yang, Jianxin Ma

Tongji University

This review presents the research progress of different preparation methods of Pt nanowire catalyst and its electrochemical performance, durability, and $\mathrm{CO}$ tolerance applying to proton exchange membrane fuel cells.

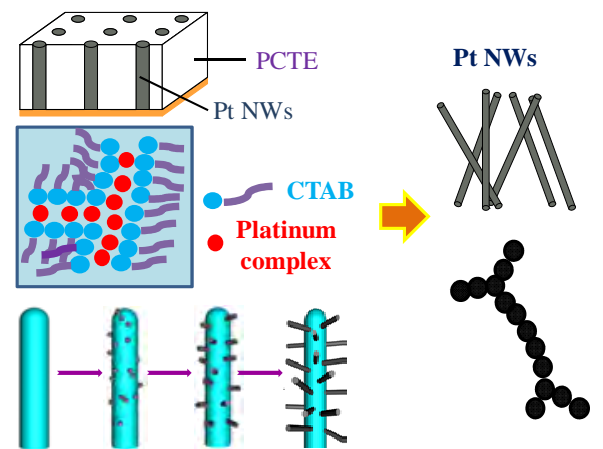

1563

[38] Li B, Higgins D C, Zhu S M, Li H, Wang H J, Ma J X, Chen Z W. Catal Commun, 2012, 18: 51

[39] Han H M, Wang T H. Micronanoelectronic Technol (韩红梅, 王太 宏. 微纳电子技术), 2002, (5): 1

[40] Zhang Y L, Guo Y G, Sun D T. Mater Sci Eng (张亚利, 郭玉国, 孙典 亭. 材料科学与工程), 2001, 19(1): 131

[41] Zhao Y. [PhD Dissertation]. Qingdao: Qingdao University (赵燕. [博 士学位论文]. 青岛: 青岛大学), 2004

[42] Zhang Y L, Guo Y G, Sun D T. Mater Sci Eng (张亚利, 郭玉国, 孙典 亭. 材料科学与工程), 2001, 19(2): 89

[43] Yang R, Bai D G. J Changchun Univ (杨锐, 白殿罡. 长春大学学报), 2008, 18(12): 47

[44] Kong L B, Li Meng K, Lu M, Guo X Y, Li H L. Chem J Chin Univ (孔令 斌, 李梦辑, 陆梅, 郭新勇, 力虎林. 高等学校化学学报), 2003, 24: 512

[45] Guan Y, Cao D M, Wu S C, Zhang H Q.J Hebei Univ Sci Technol (关钰, 曹冬梅, 吴世超, 张海黔. 河北科技大学学报), 2011, 32(2): 120

[46] Chen Y, Sha C B, Zhu X, Wu L, Gan S W, Zhu J Y, Shen Y, Chen A Q. Chem World (陈勇, 沙春豹, 朱贤, 吴龙, 甘思文, 朱瑾瑜, 沈逸, 陈安琪. 化学世界), 2009, (7): 385

[47] Sun S G, Xu H Y, Tang S H, Guo J S, Li H Q, Cao L, Zhou B, Xin Q Sun G Q. Chin J Catal (孙世国, 徐恒泳, 唐水花, 郭军松, 李焕巧, 曹雷, 周冰, 辛勤, 孙公权. 催化学报), 2006, 27: 932

[48] Park I S, Choi J H, Sung Y E. Electrochem Solid State Lett, 2008, 11
B71

[49] Choi W C, Woo S I.J Power Sources, 2003, 124: 420

[50] Choi S M, Kim J H, Jung J Y, Yoon E Y, Kim W B. Electrochim Acta, 2008, 53: 5804

[51] Ruan X, Dong L, Yu J, Yu L M, Yang Y Z. Mater Rev (阮秀, 董否, 于 晶, 于良民，杨玉鉌. 材料报导), 2012, 26(1): 56

[52] Song Y J, Garcia R M, Dorin R M, Wang H R, Qiu Y, Coker E N, Steen W A, Miller J E, Shelnutt J A. Nano Lett, 2007, 7: 3650

[53] Yang S C, Hong F, Wang L Q Guo S W, Song X P, Ding B J, Yang Z M. J Phys Chem C, 2010, 114: 203

[54] Sun S H, Zhang G X, Geng D S, Chen Y G, Li R Y, Cai M, Sun X L. Angew Chem Int Ed, 2011, 50: 422

[55] Sun S H, Yang D Q Zhang G X, Sacher E, Dodelet J P. Chem Mater, 2007, 19: 6376

[56] Sun S H, Jaouen F, Dodelet J P. Adv Mater, 2008, 20: 3900

[57] Sun S H, Zhang G X, Geng D S, Chen Y G, Banis M N, Li R Y, Cai M, Sun X L. Chem Eur J, 2010, 16: 829

[58] Sun S H, Zhang G X, Zhong Y, Liu H, Li R Y, Zhou X R, Sun X L. Chem Commun, 2009: 7048

[59] Lee H B R, Baeck S H, Jaramillo T F, Bent S F. Nano Lett, 2013, 13: 457

[60] Li Y X, Wu Q Q, Jiao S F, Xu C D, Wang L. Anal Chem, 2013, 85: 4135

[61] Shen Y L, Chen S Y, Song J M, Chin T K, Lin C H, Chen I G. Nanoscale Res Lett, 2011, 6: 380

\section{质子交换膜燃料电池Pt纳米线电催化剂研究现状}

$$
\begin{aligned}
& \text { 严泽宇 }{ }^{\mathrm{a}, \mathrm{b}} \text {, 李 } \text { 冰 }^{\mathrm{a}, \mathrm{b},{ }^{*}} \text {, 杨代军 }{ }^{\mathrm{a}, \mathrm{b}} \text {, 马建新 }{ }^{\mathrm{a}, \mathrm{b}} \\
& \text { a同济大学汽车学院, 上海 } 201804 \\
& \mathrm{~b} \text { 同济大学新能源汽车工程中心, 上海201804 }
\end{aligned}
$$

摘要: 质子交换膜燃料电池(PEMFC)能直接将化学能转换为电能, 具有能量转换效率高、环境友好、启动快等优点. 其中电催化 剂是决定PEMFC性能、寿命及成本的关键材料之一. 目前所采用的Pt催化剂成本较高, 是阻碍其商业化的主要因素. 而Pt纳米线 电催化剂的Pt利用率和催化剂活性高, 抗CO毒性以及耐久性好. 本文综述了 $\mathrm{Pt}$ 纳米线电催化剂的制备及其电化学催化性能的研 究现状.

关键词: 质子交换膜燃料电池; 电催化剂; 铂; 纳米线

收稿日期: 2013-03-18. 接受日期: 2013-05-20. 出版日期: 2013-08-20.

*通讯联系人. 电话/传真: (021)69583891; 电子信箱: libing210@tongji.edu.cn

基金来源：国家自然科学基金(21206128); 中国博士后基金(2012M510115).

本文的英文电子版由Elsevier出版社在ScienceDirect上出版(http://www.sciencedirect.com/science/journal/18722067). 


\section{1. 前言}

燃料电池是一种直接将咜存在燃料与氧化剂中的 化学能转化为电能的电化学发电装置, 具有高效 (40\%-60\%)和环境友好等特点 ${ }^{[1]}$. 其中, 质子交换膜燃 料电池(PEMFC)还具有室温启动快, 结构简单和能量密 度高等特点, 被认为是最适合电动汽车使用的车载动力 源 $^{[2]}$, 已受到各国政府、企业及相关研究机构的高度重 视. 然而, 燃料电池的商业化发展目前还受制于关键材 料费用高昂, 燃料电池耐久性差和燃料供给的基础设施 不足等 ${ }^{[3]}$. 目前, PEMFC大多采用Pt作为电极催化剂 ${ }^{[4-6]}$, 其价格昂贵且储量有限, 成为阻碍其商业化进程的一大 因素.

近年来, 人们在降低Pt载量, 提高其利用率方面进 行了大量的研究, 如采用新的载体如碳纳米管、碳纳米 纤维等来提高 $\mathrm{Pt}$ 金属的分散度 ${ }^{[7-9]}$; 或改变合金催化剂, 低Pt催化剂和非Pt催化剂等的组成 ${ }^{[10-14]}$; 或改变催化剂 的结构, 从纳米尺度上对金属催化剂的结构进行设计和 裁剪, 从而改变金属催化剂的物理化学性质, 获得性能

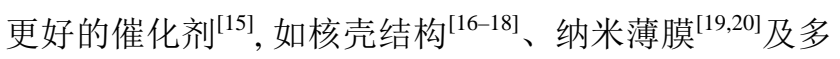
孔纳米线 ${ }^{[21]}$ 等. 其中, Pt基纳米线催化剂具有独特的结 构及表面性质, 表现出更好的催化活性、稳定性 ${ }^{[22]}$ 以及 抗CO毒性, 成为当前研究的热点. 本文对 $\mathrm{Pt}$ 基纳米线电 催化剂的制备方法及其在PEMFC中的应用进展进行了 综述.

\section{Pt纳米线催化剂简述}

三维空间尺寸至少有一维处于纳米尺度(2-50 nm) 的材料称为纳米材料, 横向上被限制在 $100 \mathrm{~nm}$ 以下的一 维结构纳米材料通常称为纳米线 ${ }^{[23,24]}$. 贵金属纳米线综 合了纳米线优良的尺寸效应和金属本身的特性, 具有不 同于块体材料的特殊物理化学性质, 在生物医学、传感 器、导电材料及化学催化等领域具有广泛的应用前 景 ${ }^{[25]}$. 目前用于PEMFC催化剂的贵金属纳米线主要有 Pd纳米线 ${ }^{[26-28]}$ 和 Pt纳米线 ${ }^{[29-32]}$. 在燃料电池运行过程 中, 碳载Pt纳米粒子随着碳载体的腐蚀而发生迁移; 此 外, Pt纳米颗粒由于具有较大的比表面积, 易发生奥氏 熟化, 从而导致 $\mathrm{Pt}$ 纳米颗粒的电化学比表面积减小, 乃 至电催化活性衰退 ${ }^{[33,34]}$, 而一维结构的Pt基纳米线则更 加稳定. 另一方面, Pt基纳米线高度有序的结构有利于 电极反应的各相传质, 并可作为良好的电子集流体 ${ }^{[35]}$, 因而Pt纳米线的催化活性以及耐久性均大大提高. 目
前, 用于PEMFC的 $\mathrm{H}_{2}$ 主要由碳氢化合物重整制得, 常常 含有CO杂质, 它也是直接甲醇燃料电池的常见中间产 物, 可导致催化剂中毒, 催化活性大大降低 ${ }^{[36]}$. 近年来, 一些研究表明相比于Pt纳米颗粒催化剂, Pt纳米线与含 氧物质的结合性弱, $\mathrm{CO}$ 在催化剂表面易流动, 促进了 $\mathrm{CO}$ 的氧化, 因而具有更好的抗CO毒性 ${ }^{[37,38]}$.

制备纳米线的方法已比较成熟, 包括激光烧蚀法、 化学气相沉积法、热气相沉积法及模板法等 ${ }^{[24,39,40]}$, 其 中, 模板法是制备Pt纳米线的主要方法. Pt纳米线的表 征技术主要包括扫描隧道显微镜(STM)、透射电子显微 镜(TEM)、扫描电子显微镜(SEM)、X射线衍射(XRD) 和X射线光电子能谱(XPS)等 ${ }^{[41,42]}$.

\section{Pt纳米线催化剂的制备及在PEMFC中的应用}

\section{1. 硬模板法}

模板法即利用模板的限域能力使材料最终具有一 定的尺寸和形状. 根据模板的结构和特点可分为硬模板 法和软模板法. 目前用于Pt纳米线合成的硬模板主要有

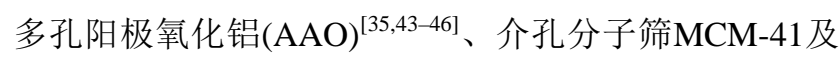
SBA-15 $5^{[47-49]}$ 和有机聚合物 ${ }^{[50]}$ 等. 其中AAO模板具有热 化学稳定性高、绝缘性能好、大小可控、排列有序和可 行性强等优点, 因而成为最常用的模板 ${ }^{[24]}$. 关钰等 ${ }^{[45]}$ 采 用 $\mathrm{AAO}$ 为模板, 电沉积 $\mathrm{PdCl}_{2}, \mathrm{H}_{2} \mathrm{PtCl}_{6}$ 和 $\mathrm{H}_{3} \mathrm{BO}_{3}$ 的混合溶 液制备了 PdPt合金纳米线阵列, 其形貌和尺寸见图1, 并 研究了该合金纳米线阵列对氢气的吸脱附性能.

张敏等 ${ }^{[35]}$ 以 $\mathrm{AAO}$ 为模板, 采用三电极法, 恒压电沉 积 $\mathrm{H}_{2} \mathrm{PtCl}_{6}$ 和 $\mathrm{H}_{3} \mathrm{BO}_{3}$ 的混合溶液, 制备了两种直径分别为 25 和 $60 \mathrm{~nm}$ 的Pt纳米线阵列(NWs), 并对两种Pt NWs催化 剂与商业 $20 \% \mathrm{Pt} / \mathrm{C}$ (Johnson Matthey)催化剂对氧还原反 应(ORR)的催化活性进行了比较, 结果见图2. Pt/C的极 限电流密度是 $0.09 \mathrm{~mA} / \mathrm{cm}^{2} ; 60$ 和 $25 \mathrm{~nm}$ 的Pt NWs则达到 0.54 和 $0.74 \mathrm{~mA} / \mathrm{cm}^{2}$, 分别是商业 $\mathrm{Pt} / \mathrm{C}$ 催化剂的 6 倍和 8 倍. Pt NWs的有序结构为反应传质以及电子传导提供了有 利条件, 因而催化活性提高; 直径小的Pt NWs的比表面 积更高从而具有更高的活性.

孙世国等 ${ }^{[47]}$ 分别以SBA-15和MCM-41介孔分子篮 作模板剂, 采用浸渍还原法, 通 $\mathrm{H}_{2}$ 还原 $\mathrm{PtCl}_{4}$ 和 $\mathrm{RuCl}_{3}$ 的乙 醇-水溶液, 制备了纵横比及合金度不同的双组元 PtRu 纳米线和纳米棒电催化剂, 结果表明, 以SBA-15为模板 制备的PtRu纳米线具有较高的合金度和较大的纵横比, 其甲醇氧化极限电流密度远高于以 MCM-41为模板制备 的PtRu纳米棒催化剂. Park等 ${ }^{[48]}$ 以 MCM-41为模板, 通 
$\mathrm{H}_{2}$ 还原 $\mathrm{Pt}\left(\mathrm{NH}_{3}\right)_{4}\left(\mathrm{NO}_{3}\right)_{2}$ 制备了直径3 nm的Pt纳米线, 并比 较了它与商业 $\mathrm{Pt} / \mathrm{C}$ 催化剂对甲醇氧化反应(MOR)的催化 活性. 在外加电压为 $0.5 \mathrm{~V}$ 时, Pt/C和Pt NWs的比表面积 活性分别为 43.30 和 $113.20 \mu \mathrm{A} / \mathrm{cm}^{2}$, 比质量活性分别为 6.58 和 $10.84 \mathrm{~A} / \mathrm{g}$, 说明使用相同Pt载量时, Pt NWs表现出 更好的催化活性. Choi等 ${ }^{[49]}$ 以SBA-15为模板, 通 $\mathrm{H}_{2}$ 还原 $\left(\mathrm{NH}_{3}\right)_{4} \mathrm{Pt}\left(\mathrm{NO}_{3}\right)_{2}$ 和 $\left(\mathrm{NH}_{3}\right)_{6} \mathrm{RuCl}_{3}$ 制备了 $\mathrm{PtRu}$ 合金纳米线, 它在半电池测试和单电池测试中都表现出比商业PtRu 黑催化剂更好的性能.

Choi 等 ${ }^{[50]}$ 以径迹蚀刻聚碳酸酯(PCTE)为模板, 电沉 积 $\mathrm{H}_{2} \mathrm{PtCl}_{6}$ 和 $\mathrm{H}_{2} \mathrm{SO}_{4}$ 的混合溶液, 制备了直径约 $49 \mathrm{~nm}$ 的 $\mathrm{Pt}$ 纳米线, 其制备过程如图3所示. 发现该 $\mathrm{Pt}$ 纳米线催化剂 表现出较好的MOR活性, 比质量活性为 $57.2 \mathrm{~mA} / \mathrm{mg}$, 远 高于商业Pt/C (39.4 mA/mg) 和纯 Pt黑 $(29.7 \mathrm{~mA} / \mathrm{mg}$ )催化 剂; 同时还表现出较好的抗CO毒性.

在硬模板法中, AAO模板具有孔径大小一致、分布 均匀、排列有序的特点, 且其孔径以及膜厚可以通过改 变电解条件来进行控制, 成为研究和应用较为广泛的纳 米模板材料. 介孔分子篮模板孔径约在1.5-10 $\mathrm{nm}$ 之间, 比AAO模板(5-200 nm) 更小. 有机聚合物通常经过径迹 蚀刻处理后作为合成纳米材料的模板, 孔的分布不均匀 且无规律, 膜内存在多孔通道交叉的现象, 导致合成的 纳米材料不能形成有序的阵列体.

\section{2. 软模板法}

软模板法是指模板剂通过非共价键作用力, 结合电 化学和沉淀法等技术, 使反应物在纳米尺度的孔隙间反 应, 并利用其空间限制作用和调节作用有效地控制合成 材料的尺寸及形貌 ${ }^{[51]}$. 目前该法大多以十六烷基三甲 基溴化铵(CTAB)为模板剂来合成Pt纳米线.

Song等 ${ }^{[52]}$ 将 $\mathrm{K}_{2} \mathrm{PtCl}_{4}$ 水溶液和 CTAB 的氯仿溶液混 合搅拌, 形成水-氯仿两相系统, CTAB分子在氯仿液滴 内形成蠕虫状胶束网络结构, $\mathrm{K}_{2} \mathrm{PtCl}_{4}$ 在 $\mathrm{NaBH}_{4}$ 作还原剂, 磁力搅拌的条件下复制 CTAB的结构, 从而合成Pt纳米 线网络结构, 其形成机理如图4所示. 此外, 他们还发现, 当磁力摚拌速度较小时, 产物主要为 Pt 纳米颗粒, 当磁 力摚拌速度增大, 产物主要为 $\mathrm{Pt}$ 纳米线, 这是由于摚拌 速度较大时能够形成更多的氯仿液滴并加快 $\mathrm{NaBH}_{4}$ 从 水中扩散到氯仿中, 从而增加 CTAB 分子网状胶束内 $\mathrm{K}_{2} \mathrm{PtCl}_{4}$ 还原反应的发生几率, 且较快的反应速度使 $\mathrm{Pt}$ 更 好地复制 CTAB的结构; 相反, 当摚拌速度较小时, 反应 速度慢, CTAB分子适应了Pt的结晶和生长, 从而形成纳 米颗粒. 另外, Pt前驱体的浓度可影响生成 $\mathrm{Pt}$ 纳米线的
直径: 前驱体浓度较小时, 产物中Pt纳米线直径较小, 甚 至因为缺乏足够的Pt连接形成纳米线而形成单独的纳 米颗粒.

在此方法基础上, Yang等 ${ }^{[53]}$ 制备了 PtRu, PtPd, PtAu 和 $\mathrm{PtFe}$ 等合金纳米线, 并发现在制备 $\mathrm{PtFe}$ 纳米线时, 因 $\mathrm{Pt}^{4+}$ 和 $\mathrm{Fe}^{3+}$ 的还原电位相差很大, 需要加大还原剂 $\mathrm{NaBH}_{4}$ 的用量. Wang等 ${ }^{\left[{ }^{[7]}\right.}$ 用该法制备了直径约为 $2.5 \mathrm{~nm}$ 的 $\mathrm{Pt}$ 纳米线网 (Pt NWN)催化剂, 研究了它们的MOR活性和 抗CO毒性, 并与商业 Pt/C纳米颗粒催化剂(E-TEK)进行 比较, 其 $\mathrm{CO}$ 剥离脱附 $\mathrm{CV}$ 曲线和甲醇氧化 $\mathrm{CV}$ 曲线分别如 图5和图6所示. 可以看出, 相比于 Pt/C, Pt NWN/C的CO 氧化峰电位和起始氧化电位都出现了不同程度的负移, 表明Pt NWN吸附的CO更易被氧化. Pt催化剂吸附的 $\mathrm{CO}$ 氧化反应如下:

$$
\begin{gathered}
\mathrm{H}_{2} \mathrm{O}+\mathrm{Pt} \rightarrow \mathrm{Pt}-\mathrm{OH}_{\mathrm{ads}}+\mathrm{H}^{+}+\mathrm{e}^{-} \\
\mathrm{Pt}-\mathrm{CO}_{\mathrm{ads}}+\mathrm{Pt}-\mathrm{OH}_{\mathrm{ads}} \rightarrow \mathrm{CO}_{2}+\mathrm{H}^{+}+\mathrm{e}^{-}+\mathrm{Pt}
\end{gathered}
$$

$\mathrm{Pt}$ 催化剂临近位点上吸附的 $\mathrm{CO}$ 与 $\mathrm{OH}$ 发生电化学反 应而被氧化, 因此, $\mathrm{CO}_{\mathrm{ads}}$ 和 $\mathrm{OH}_{\mathrm{ads}}$ 在Pt表面的流动性对 $\mathrm{CO}$ 氧化反应具有很大的影响. 相比于Pt NPs, Pt NWNs吸 附含氧物质的能力较弱, 导致其表面的 $\mathrm{CO}_{\mathrm{ads}}$ 和 $\mathrm{OH}_{\mathrm{ads}}$ 容 易扩散和混合, 从而加快 $\mathrm{CO}$ 电化学氧化反应. 此外, $\mathrm{Pt}$ NWNs内部相互连接的结构也为CO氧化反应提供了更 多的活性位点. 可见, Pt纳米线吸附的CO更容易被氧化, 因而Pt纳米线表现出更好的抗CO毒性.

由图6可见, 正扫时Pt NWNs/C和Pt/C的峰值电流密 度分别为 0.96 和 $0.29 \mathrm{~mA} / \mathrm{cm}^{2}$, 表明 $\mathrm{Pt}$ NWNs具有更好的 MOR活性. 同时, 正扫和回扫电流峰值比 $I_{\mathrm{f}} / I_{\mathrm{b}}$ 通常被用 来表征催化剂的抗CO中毒性能, 可见Pt $\mathrm{NWNs} / \mathrm{C}$ 和Pt/C 的 $I_{\mathrm{f}} / I_{\mathrm{b}}$ 分别为 0.96 和 0.76 , 表明前者具有更好的抗 CO毒 性.

$\mathrm{Li}^{\text {等 }}{ }^{[38]}$ 用该方法制备了 PtRu合金纳米线, 并研究了 还原剂用量以及 $\mathrm{Pt}: \mathrm{Ru}$ 原子比对催化剂 $\mathrm{MOR}$ 活性的影响. 结果表明, 当还原剂 $\mathrm{NaBH}_{4}$ 用量为 $0.4 \mathrm{~g}, \mathrm{Pt}: \mathrm{Ru}$ 原子比为 $1: 1$ 时, $\mathrm{PtRu}$ 纳米线的催化活性最好. 当外加电压为 $0.7 \mathrm{~V}$ 时, 该样品的电流密度为 $30.95 \mathrm{~mA} / \mathrm{cm}^{2}$, 高于目前具有 最好MOR活性 $\left(23.5 \mathrm{~mA} / \mathrm{cm}^{2}\right)$ 以及抗CO中毒性能的商业 Pt-Ru黑催化剂.

\section{3. 无模板法}

无模板法合成Pt纳米线主要是采用室温 $\mathrm{HCOOH}$ 还 原 $\mathrm{H}_{2} \mathrm{PtCl}_{6}$ 的方法 ${ }^{[54-58]}$, Pt的还原按照下式进行:

$\mathrm{H}_{2} \mathrm{PtCl}_{6}+2 \mathrm{HCOOH} \rightarrow \mathrm{Pt}+6 \mathrm{Cl}^{-}+6 \mathrm{H}^{+}+2 \mathrm{CO}_{2} \uparrow$ 室温下较慢的反应速率促进了 $\mathrm{Pt}$ 晶体沿着 $<111>$ 方 
向生长, 从而形成 $\mathrm{Pt}$ 纳米线, 但是其准确的形成机理尚 待研究 ${ }^{[54]}$. Sun等 ${ }^{[55]}$ 将适量的多壁碳纳米管(MWCNTs) 加入 $\mathrm{H}_{2} \mathrm{PtCl}_{6}$ 和 $\mathrm{HCOOH}$ 的混合溶液中, 于室温下反应 $3 \mathrm{~d}$, Pt直接在碳纳米管壁结晶形成纳米线, 如图7所示.

Sun等 ${ }^{[56]}$ 还采用该法制备了Vulcan XC72碳载体Pt 纳米线, 研究了反应时间以及前驱体浓度对碳纳米球表 面生成Pt纳米线的长度和密集程度的影响, 并考察了该 催化剂在膜电极(MEA)中催化ORR反应的性能, 与商业 $\mathrm{MEA}(\mathrm{Gore})$ 进行了对比, 结果见图8. 从图中可以看出, 相比商业 $\mathrm{Pt} / \mathrm{C}$ 催化剂, Pt NWNs/C催化剂表现出较好的 性能, 在任意给定的电流密度下, 其输出电压均升高了 10-12 mV, 这可能是由于该催化剂具有更好的ORR反应 动力学.

表1为这两种催化剂MEA性能的相关参数. 可以看 出, 使用Pt NWS/C催化剂的MEA的Pt载量相对较小, 但 其性能更好. Pt NWS催化剂粒径较大, 具有互相连接的 结构, 因而其电化学比表面积小于Pt纳米颗粒催化剂, 但在 $0.9 \mathrm{~V}$ 时比质量活性提高了 $50 \%$, 其原因可能是单晶 $\mathrm{Pt}$ 纳米线暴露的晶面具有更高的ORR活性以及Pt纳米线 的有序结构利于反应传质.

Sun等 ${ }^{[54]}$ 通过加速耐久性测试研究了自制的单晶多 臂星形Pt纳米线在循环扫描 4000 转后电化学性能的变 化, 并和商业 $\mathrm{Pt} / \mathrm{C}$ 催化剂进行了对比, 发现 Pt NWs/C具 有更好的耐久性, 而且去除碳载体之后, 其耐久性进一 步提升, 表明Pt NWs 具有相对稳定的结构.

如图9所示, 商业Pt/C催化剂的循环伏安曲线测试前 后氢的吸脱附峰面积大幅度减小, 表明经过 4000 转测试 之后, $\mathrm{Pt} / \mathrm{C}$ 的电化学活性面积损失最多. 随着循环转数 的增加, 三种催化剂的电化学比表面积均逐渐减小, 其 中以商业 $\mathrm{Pt} / \mathrm{C}$ 下降的幅度最为明显. 测试结果表明, 商 业 $\mathrm{Pt} / \mathrm{C}$ 的电化学比表面积损失了 $67.5 \%$, 而 $\mathrm{Pt} \mathrm{NWs} / \mathrm{C}$ 和 无碳载体的Pt NWs分别损失了 $40 \%$ 和 $13 \%$, 说明后两个 电催化剂的稳定性明显优于商业 $\mathrm{Pt} / \mathrm{C}$. 另外, 无碳载体 的Pt NWNs的耐久性进一步提高.

由图10可以看出, 加速测试后商用 $\mathrm{Pt} / \mathrm{C}$ 的催化性能 也出现了大幅度的下降, 测试结果表明, $\mathrm{Pt} / \mathrm{C}$ 损失了 88 $m V$ 半峰电压, 而Pt NWs/C和Pt NWs的分别下降了 20 和 9 $\mathrm{mV}$. 图11表明了测试过程中不同催化剂形貌改变的机 理, 商业Pt/C催化剂主要由于发生 Pt纳米颗粒发生奥氏 熟化或聚集, 以及碳载体的腐蚀从而导致其电化学比表 面积下降. 而Pt NWs 具有较稳定的一维结构和较低的 表面能, 测试前后其外形结构几乎不发生变化, Pt
$\mathrm{NWs} / \mathrm{C}$ 的损耗也主要由于碳载体的腐蚀. 该结果表明, Pt NWs因为其独特的结构具有更好的耐久性.

除采用甲酸还原方法外, Lee等 ${ }^{[59]}$ 利用高定向热解 石墨(HOGC)层状结构的特点, 使用原子层沉积法(ALD) 在具有缺陷位的HOGC阶梯状边缘沉积制备Pt纳米线, 并通过改变ALD循环周期实现了对 Pt纳米线直径的控 制. Li 等 ${ }^{[60]}$ 对自制的Pt圆盘纳米电极进行 HF 酸蚀刻处 理后, 通过欠电位(UPD)还原置换制备了单根Pt纳米线 电极, 并研究了形貌对电极的ORR活性及传质速率的影 响. 结果表明, 长度较短的电极具有较快的传质速率, $\mathrm{Pt}$ 纳米线电极的尖端比壁面具有更高的ORR活性, 且随电 极长度的增加活性降低. Shen等 ${ }^{[61]}$ 将 $\mathrm{Na}_{2} \mathrm{Pt}(\mathrm{OH})_{6}$ 溶液滴 加到 $\mathrm{TiO}_{2}$ 涂覆的基体表面, 然后在红外炉中于 $300{ }^{\circ} \mathrm{C}$ 加 热 $3 \mathrm{~h}$, 利用 $\mathrm{TiO}_{2}$ 的光催化特性, 制备了平均直径为 34 $\mathrm{nm}$, 长度约为 $6 \mu \mathrm{m}$, 纵横比达到 200 的Pt纳米线.

总之, 使用软模板法制备的Pt纳米线直径较小, 约 为 $2.5 \mathrm{~nm}$ 左右; 使用硬模板法制备的纳米线形态均一可 控, 并可制备纳米线阵列; 使用 $\mathrm{HCOOH}$ 直接还原制备 的Pt纳米线具有单晶结构的特点. 可以看出, 硬模板法 主要存在 4 个不足: (1)硬模板连续性差, 导致所制备的 催化剂金属相互联结性低; (2)硬模板的去除通常使用 氢氟酸, 严重威胁环境和安全; (3) 硬模板的孔结构通常 会制约纳米催化剂结构和尺寸; (4)硬模板通常价格昂 贵, 不易批量生产. 相比而言, 软模板法更容易灵活控制 燃料电池所用 $\mathrm{Pt}$ 基纳米线催化剂的结构和尺寸, 且环境 友好, 价格便宜, 更容易实现规模化生产.

\section{4. 小结}

降低Pt担载量, 提高其利用率, 开发高性能的 $\mathrm{Pt}$ 电催 化剂对推动燃料电池商业化具有重大意义. Pt基纳米线 电催化剂因其独特的一维结构及特殊的表面性质, 表现 出比商业Pt纳米颗粒电催化剂更高的ORR和MOR活性、 抗CO毒性及耐久性. 目前制备Pt基纳米线的方法日渐 成熟, 主要包括以 $\mathrm{AAO}$ 和介孔分子篮等为模板的硬模板 法、以 $\mathrm{CTAB}$ 等为模板的软模板法、以及直接室温下使 用 $\mathrm{HCOOH}$ 还原 $\mathrm{H}_{2} \mathrm{PtCl}_{6}$ 等前驱体的分子自组装法等. 因 此, $\mathrm{Pt}$ 基纳米线电催化剂最有希望实现低Pt电催化剂. 然而, Pt 基纳米线电催化剂的研究仍面临以下问题: 寻 找较好地控制Pt纳米线外形结构, 适用于大规模生产的 制备方法; 揭示纳米线的独特结构对电催化动力学的影 响; 探索 $\mathrm{Pt}$ 基纳米线电催化剂活性提高的机理, 为制备 高性能催化剂提供理论依据. 